\title{
SEROPREVALENCE OF NMO-IgG ANTIBODY IN BRAZILIAN PATIENTS WITH NEUROMYELITIS OPTICA
}

\author{
Tarso Adoni', Angelina Maria Martins Lino², Paulo Euripedes Marchiori', \\ Fernando Kok ${ }^{3}$, Dagoberto Callegaro ${ }^{4}$
}

\begin{abstract}
Objective: To determine the seroprevalence of neuromyelitis optica antibody (NMO)-IgG in Brazilian patients with clinical diagnosis of relapsing neuromyelitis optica, also known as Devic's disease. Method: We determined NMO-IgG titers in 28 patients (25 of them females) that fulfilled the 1999 NMO diagnostic criteria proposed by Wingerchuk et al. Results: NMO-IgG was detected in 18 NMO patients (64.3\%). Conclusion: Our results showed that seroprevalence of NMO-IgG in Brazilian NMO patients was similar to the observed in other studies.
\end{abstract}

KEY WORDS: neuromyelitis optica, Devic's disease, NMO-IgG, seroprevalence.

\begin{abstract}
Soroprevalência do anticorpo NMO-IgG em pacientes brasileiros com neuromielite óptica
Resumo - Objetivo: Determinar a soroprevalência do anticorpo neuromielite óptica (NMO)-lgG em pacientes brasileiros com diagnóstico de neuromielite óptica recorrente, também conhecida como doença de Devic. Método: Nós pesquisamos a presença do anticorpo NMO-IgG em 28 pacientes ( 25 do sexo feminino) que preenchiam os critérios diagnósticos para NMO propostos por Wingerchuk et al. em 1999. Resultados: Dezoito pacientes $(64,3 \%)$ apresentaram a pesquisa positiva do NMO-IgG. Conclusão: Nossos resultados demonstraram que a soroprevalência do anticorpo NMO-IgG em pacientes brasileiros com NMO é semelhante àquela encontrada em outros estudos.
\end{abstract}

PALAVRAS-CHAVE: neuromielite óptica, doença de Devic, NMO-IgG, soroprevalência.

Neuromyelitis optica (NMO; Devic's disease) and its spectrum disorders are idiopathic inflammatory demyelinating diseases of the central nervous system (CNS) that mainly affect the optic nerves and spinal cord'. The hallmark of NMO pathology is the presence of necrotic spinal cord lesions involving both gray and white matter, often resulting in cavitation, as well as the presence of vascular hyalinization ${ }^{2}$. NMO and multiple sclerosis (MS) are currently considered different diseases since the description of NMO-IgG, a serum gamma immunoglobulin autoantibody that is a specific marker for $\mathrm{NMO}^{3,4}$. NMO-IgG selectively binds to aquaporin-4 (AQP4) water channel, a component of the dystroglycan protein complex of astrocytic foot processes at the blood-brain barrier. ${ }^{5}$. Its sensitivity and specificity for NMO diagnosis were confirmed in several studies and the presence of NMO-IgG is now one of the new diagnostic criteria for neuromyelitis optica ${ }^{4}$.

NMO may represent the first example of a novel class of autoimmune channelopathy ${ }^{5}$. The clinical course of NMO is usually more severe than of MS. Within five years of onset, fifty percent of patients either lose functional vision in at least one eye or become unable to walk unassisted $^{6}$. Detection of the autoantibody enables early diagnosis of NMO, before the presence of a full-blown clinical picture, allowing early initiation of appropriate immunosuppressive therapy.

This is the first study of frequency of NMO-lgG in a series of Brazilian relapsing NMO patients.

\section{METHOD}

Twenty-eight patients with NMO from the Center for Myelin Disorders of the Neurologic Clinic of São Paulo University School of Medicine, São Paulo, Brazil, were enrolled. All of them fulfilled the original criteria for diagnosis of $\mathrm{NMO}^{6}$. Demographic and clinical characteristics of patients included in our study are shown on Table 1. Briefly, median age at onset of disease was 27 years (range 7-51), median time of follow-up was 8 years (range 1-14). The mean time elapsed between optic neuritis and myelitis was 18 months (median 21; range 2-60), Kurtzke's Expanded Disease Severity Score on last visit was 6.0 (range 2-8).

Department of Neurology, University of São Paulo School of Medicine, São Paulo SP, Brazil: ${ }^{M D} ;{ }^{2} \mathrm{MD}, \mathrm{PhD} ;{ }^{3} \mathrm{MD}$, PhD, Associate Professor; ${ }^{4} \mathrm{MD}$, PhD, Center for Myelin Disorders of Hospital das Clínicas, Chairman.

Received 13 December 2007, received in final form 8 April 2008. Accepted 24 April 2008.

Dr. Tarso Adoni - Rua Barata Ribeiro 414 / 41 -01308-000 São Paulo SP - Brasil. E-mail: tarso@dfvneuro.com.br 
Table 1. Demographic and clinical characteristics of patients with neuromyelitis optica.

\begin{tabular}{lc}
\hline Gender & 3 \\
Male & 25 \\
Female & \\
Age at onset (years) & 27 \\
$\quad$ Median & $7-51$ \\
$\quad$ Range & \\
Ethnical origin & 20 \\
African descents & 7 \\
European descents & 1 \\
$\quad$ Asian descents & \\
Duration of follow-up ( years) & 8 \\
$\quad$ Median & $1-14$ \\
Range & \\
Time elapsed between optic & 21 \\
neuritis and myelitis (months) & $2-60$ \\
Median & \\
Range & \\
EDSS on last clinical visit & \\
Median & \\
Range & $2-0$ \\
\hline
\end{tabular}

All patients presented with recurrent disease and were receiving azathioprine ( $3 \mathrm{mg} / \mathrm{kg}$ daily) when a blood sample was drawn for this study and sent to Mayo Clinic Rochester, Rochester, Minnesota, USA. Serum NMO-IgG was detected using the methodology described by Lennon et al. ${ }^{3}$ at Mayo Clinic. All subjects or their legal responsible signed the Informed Consent Form, and the study was approved by the Institutional Review Board and conducted in compliance with the Declaration of Helsinki.

\section{RESULTS}

Serum NMO-IgG was detected in 18 (64.3\%) of the 28 patients enrolled. Female to male ratio was $8.3: 1$ and $75 \%$ of patients were non-whites.

\section{DISCUSSION}

There are descriptions of the frequency of NMO-IgG in NMO patients in different populations ${ }^{7}$ (Table 2). The first publication included 102 North American patients with NMO or with high-risk syndromes for NMO (recurrent optic neuritis or longitudinally extensive transverse myelitis), and 12 Japanese patients with optic-spinal multiple sclerosis (OSMS). In that seminal paper the authors found sensitivity and specificity for NMO diagnosis of $73 \%$ and $91 \%$, respectively ${ }^{3}$. In Japan, authors detected NMOIgG in more than half of OSMS patients (63\% sensitivity) $)^{8}$, suggesting that NMO and OSMS could be the same entity.

The prevalence of NMO and MS varies significantly among different regions of the world ${ }^{15,16}$. Such differences are due to variability in genetic susceptibility and environmental factors ${ }^{17}$. MS in North American individuals of European extraction is associated with human leukocyte antigen (HLA) DRB1*1501 (DR2), while Asian individuals with HLA $\mathrm{DPB}^{*} 0501$ have a higher risk for NMO. Interestingly, HLA $\mathrm{DPB}^{*} 0501$ is present in $60 \%$ of the normal people in Japan, but in less than $10 \%$ of the North American population ${ }^{18-21}$.

In Brazil, HLA DQB1, DQA1 and DRB1 genotype variability according to ethnicity was analyzed ${ }^{22}$. The authors concluded that DQA1*0201-0301 alleles were associated with white Brazilian population and the DRB*1501 allele was present in European-Brazilians and DRB1*03-1503 in African-Brazilians; the DRB1* 1501 allele confers an ethnicity-dependent MS susceptibility in European patients whereas DQB1*0602 allele confers genetic susceptibility regardless of ethnicity ${ }^{22}$. Maybe these findings could explain the higher prevalence of NMO in patients with African ancestry in virtue of ethnicity-dependent susceptibility. In our sample of 28 patients with NMO, 18 were seropositive for the NMO-IgG antibody, 15 of them African descents and only 3 European descents.

To our knowledge this is the first report on the frequency of NMO-IgG as a serological marker for NMO in Brazilian patients. In our series, among clinically defined NMO patients, NMO-IgG was positive in $64.3 \%$. This seroprevalence is similar to that observed by others ${ }^{3,8}$.

In a recent study ${ }^{23}$, multiple logistic analyses revealed that emergence of the anti-NMO-IgG antibody was

Table 2. Frequency of anti-aquaporin 4 antibody in different populations.

\begin{tabular}{lccc}
\hline Author & Country & NMO/OSMS (n) & Positive \% \\
\hline Zuliani, 2006 & Spain & 10 & 50 \\
Littleton, 2006 & UK & 10 & 50 \\
Kim, 2006 & Korea & 27 & 19 \\
Marignier, 2006 & France & 20 & 55 \\
Jarius, 2007 & Europe & 35 & 54 \\
Akman-Demir, 2006 & 14 & 14 & 57 \\
Present study & Turkey & 28 & 64.3 \\
\hline
\end{tabular}


positively associated with a higher relapse rate. Thus, this method can be a useful and reliable tool in NMO diagnosis and management in Brazilian patients, in spite of ethnical differences and genetic peculiarities of our population. We hope that early detection of NMO-IgG in Brazilian patients with $\mathrm{NMO}$ and high-risk syndromes for NMO assures prompt and appropriate therapy.

\section{REFERENCES}

1. Weinshenker BG. Neuromyelitis optica is distinct from multiple sclerosis. Arch Neurol 2007;64:899-901.

2. Mandler RN, Davis LE, Jeffery DR, Kornfeld MK. Devic's neuromyelitis optica: a clinicalpathological study of 8 patients. Ann Neurol 1993;34:162-168

3. Lennon VA, Wingerchuk DM, Kryzer TJ, et al. A serum autoantibody marker of neuromyelitis optica: distinction from multiple sclerosis. Lancet 2004;364:2106-2112.

4. Wingerchuk, DM. Neuromyelitis optica. Int MSJ 2006;13:42-50.

5. Lennon VA, Kryzer TJ, Pittock SJ, Verkman AS, Hinson SH. IgG marker of optic-spinal multiple sclerosis binds to the aquaporin- 4 water channel. J Exp Med 2005;202:473-477.

6. Wingerchuk DM, Hogancamp WF, O'Brien PC, Weinshenker BG. The clinical course of neuromyelitis optica (Devic's syndrome). Neurology 1999;53:1107-1114.

7. Jacob A, Matiello M, Wingerchuk DM, Lucchinetti, Pittock SJ and Weinshenker B. Neuromyelitis óptica: changing concepts. J Neuroimmunol 2007; 187:126-138

8. Nakashima I, Fujihara K, Miyazawa I, et al. Clinical and MRI features of Japanese MS patients with NMO-IgG. J Neurol Neurosurg Psychiatry 2006;77:1073-1075.

9. Zuliani L, Blanco Y, Tavolato B, Giometto B, Graus F and Saiz A. Neuromyelitis optica autoantibody (NMO-IgG) in patients with suspected NMO or limited forms of NMO. Mult Scler 2006;12:S155.
10. Littleton ET, Jacob A, Boggild M, Palace J. An audit of the diagnostic usefulness of the NMO-IgG assay for neuromyelitis optica. Mult Scler 2006;12:S156.

11. Kim KK. NMO-IgG and opticospinal multiple sclerosis and idiopathic recurrent myelitis. Mult Scler 2006;12:S157.

12. Marignier R, De Seze J, Durand-Dubief F, et al. NMO-IgG: a French experience. Mult Scler 2006;12:S4.

13. Jarius S, Franciotta D, Bergamaschi R, et al. NMO-IgG in the diagnosis of neuromyelitis optica. Neurology 2007;68:1076-1077.

14. Akman-Demir G, Mutlu M Icoz S, Kurtuncu M, Yesilot N, Eraksoy M. Probable NMO-IgG in Turkish patient with Devic's disease, and multiple sclerosis. Mult Scler 2006;12:S157.

15. Mirsattari SM, Johnston JB, McKenna R, et al. Aboriginals with multiple sclerosis: HLA types and predominance of neuromyelitis optica. Neurology 2001;56:317-323.

16. Papais-Alvarenga RM, Miranda-Santos CM, Puccioni-Sohler M, et al.Optic neuromyelitis syndrome in Brazilian patients. J Neurol Neurosurg Psychiatry 2002;73:429-435.

17. Gilden DH. Viruses and multiple sclerosis. JAMA. 2001;286:3127-3129

18. Fernandez O, Fernandez V, Alonso A, et al. DQB1*0602 allele shows a strong association with multiple sclerosis in patients in Malaga, Spain. J Neurol 2004;251:440-444.

19. Kira J. Multiple sclerosis in the Japanese population. Lancet Neurol 2003;2:117-127.

20. Naito S, Kuroiwa Y, Itoyama T, et al. HLA and Japanese MS. Tissue Antig 1978;12:19-24.

21. Weinshenker BG, Santrach P, Bissonet AS, et al. Major histocompatibility complex class II alleles and the course and outcome of MS: a population-based study. Neurology 1998;51:742-747.

22. Alves-Leon SV, Papais-Alvarenga R, Magalhães M, Alvarenga M, Thuler LCS, Fernández y Fernández O. Ethnicity-dependent association of HLA DRB1-DQA1-DQB1 alleles in Brazilian multiple sclerosis patients. Acta Neurol Scand 2007;115:306-311.

23. Matsuoka T, Matsushita T, Kawano Y, et al. Heterogeneity of aquaporin-4 autoimmunity and spinal cord lesions in multiple sclerosis in Japanese. Brain 2007;130:1206-1223. 